\title{
AGM1+ Spleen Cells Contain Gamma Interferon (IFN- $\gamma$ ) Gene Transcripts in the Early, Sex-Dependent Production of IFN- $\gamma$ after Picornavirus Infection
}

\author{
HUGH I. MCFARLAND $\dagger$ AND NANCY J. BIGLEY* \\ Department of Microbiology and Immunology, School of Medicine, and College of Science \\ and Mathematics, Wright State University, Dayton, Ohio 45435
}

Received 25 January 1990/Accepted 11 June 1990

\begin{abstract}
Encephalomyocarditis D variant (EMCV-D)-infected spleen cell cultures prepared from diabetes-resistant ICR Swiss female mice produce more gamma interferon (IFN- $\gamma$ ) activity over a 24-h period than do spleen cell cultures from diabetes-susceptible male mice of this strain. Pretreatment of mice with anti-asialo GM1 eliminates early in vitro IFN- $\gamma$ production from 4 to $16 \mathrm{~h}$ postinfection (p.i.) and reduces IFN- $\gamma$ production from 16 to $24 \mathrm{~h}$ p.i. In this study, depletion of spleen cells with anti-Thy-1 by panning greatly reduced IFN- $\gamma$ activity in EMCV-D-infected spleen cell cultures throughout a 24-h period. Populations of asialo GM1 (AGM1), L3T4, and Lyt-2-positive cells were isolated from cells harvested at 9 h p.i. from EMCV-D-infected spleen cell cultures by a modified panning technique on polystyrene microscope slides. By in situ hybridization with a $\left[{ }^{35}\right.$ S]dATP-labeled IFN- $\gamma$ cDNA probe, only the AGM1-bearing cells were found to contain detectable IFN- $\gamma$ gene transcripts. An AGM1+, Thy-1+ natural killer-like cell is the probable producer of the early, sex-dependent IFN- $\gamma$ activity in this system.
\end{abstract}

Encephalomyocarditis D variant (EMCV-D) infection of susceptible mouse strains results in a disease state similar to human insulin-dependent diabetes mellitus (25). Male ICR Swiss mice are diabetes susceptible, and females of this strain are diabetes resistant (6). Female ICR Swiss mice pretreated with testosterone are rendered susceptible to EMCV-D-induced diabetes (6), and males of this strain become diabetes resistant after estradiol pretreatment (D. J. Giron, personal communication). Female ICR Swiss mice are made susceptible to EMCV-D-induced diabetes by impairment of macrophage phagocytic function with type I carrageenan, and males of this strain become resistant following pretreatment with concanavalin A or interleukin-2 (IL-2), inducers of multiple cytokines including gamma interferon (IFN- $\gamma$ ) (2). These findings suggested that early, nonspecific antiviral mechanisms are important in resistance to EMCV-D infection. We have recently shown (16) that EMCV-D-infected spleen cell cultures prepared from female ICR Swiss mice produce a larger early (4 to $16 \mathrm{~h}$ postinfection [p.i.]) IFN- $\gamma$ response than do identically treated spleen cell cultures from ICR Swiss male mice. This early IFN- $\gamma$ production can be eliminated by pretreatment of mice with rabbit anti-AGM1 (AAGM1) and is reduced but not eliminated by neutralization of cultures with anti-murine IL-2. Later ( 20 to $24 \mathrm{~h}$ p.i.), IFN- $\gamma$ production by spleen cells from both sexes is reduced but not eliminated by rabbit AAGM1 pretreatment of mice. IL-2 is required for production of this later IFN- $\gamma$ activity. Here, we report that depletion of Thy-1+ cells prior to culture virtually eliminated IFN- $\gamma$ production by spleen cell cultures from both sexes over a $24-\mathrm{h}$ period. The cell type responsible for the early, sex-dependent IFN- $\gamma$ production was identified as an AGM1 + natural killer (NK)-like cell by in situ hybridization with an IFN- $\gamma$ cDNA probe.

\footnotetext{
* Corresponding author.

$\dagger$ Present address: Department of Pathology, University of Massachusetts Medical Center, Worcester, MA 01655.
}

\section{MATERIALS AND METHODS}

Virus. EMCV-D was obtained from D. J. Giron (Wright State University, Dayton, Ohio) and was propagated as previously described (7). The EMCV-D stock was passaged five times through L929 cells, twice through BHK21 cells, and again five times through L929 cells. This virus stock is diabetogenic in 8 of 10 male ICR Swiss mice tested.

Animals. ICR Swiss mice were purchased from Harlan Laboratories (Indianapolis, Ind.). The specific-pathogenfree colony of ICR Swiss mice was monitored monthly by Harlan Laboratories to ensure their virus-free state, and mice were shipped in filtered crates. Upon arrival at the Laboratory for Animal Resources at Wright State University, the mice were placed in a separate room with no other animals. Mice were housed in groups of five and rested for at least 1 week prior to use. The mice were maintained in an individual animal room at positive pressure which received triple-filtered air. At 9 weeks of age, the mice were killed by cervical dislocation and their spleens were aseptically removed.

Spleen cell culture. Spleen cells were obtained by maceration of spleens between the frosted ends of flame-sterilized glass microscope slides as previously described (16). The cells were collected in a petri dish containing RPMI 1640 (Sigma Chemical Co., St. Louis, Mo.) which was prepared by using endotoxin (pyrogen)-free water. All media used were prewarmed to $37^{\circ} \mathrm{C}$. To remove spleen debris, the cell suspension was transferred to a $50-\mathrm{ml}$ centrifuge tube and allowed to stand for 10 minutes at room temperature (RT). Following this incubation, the cell suspension was transferred to another tube; care was taken not to disturb the sediment. The spleen cells were washed once with $50 \mathrm{ml}$ of RPMI 1640 and suspended in RPMI 1640 supplemented with $10 \%$ calf serum (Hyclone, Logan, Utah) containing $0.037 \mathrm{ng}$ or less of endotoxin per $\mathrm{ml}$ and $50 \mu \mathrm{g}$ of gentamicin sulfate per ml (GIBCO, Baltimore, Md.) (complete medium). To 24-well tissue culture plates (Corning Glass Works, Corning, N.Y.), $3.75 \times 10^{6}$ nucleated spleen cells per well were 
added. Culture wells to be infected were treated with EMCV-D at a multiplicity of infection of 0.1 at time zero.

IFN- $\boldsymbol{\gamma}$ assay. As described previously, antiviral assays were performed by using a microwell plaque reduction assay with vesicular stomatitis virus as the challenge virus (16). IFN- $\gamma$ antiviral activity was typed by using hamster antimouse IFN- $\gamma$ produced by hybridoma MPH 5.102.12, a gift from S. W. Russell, presently at the University of Kansas Medical Center, Kansas City, Kans. Test samples were incubated for $1 \mathrm{~h}$ at $37^{\circ} \mathrm{C}$ with 800 neutralizing units of anti-mouse IFN- $\gamma$ prior to assaying them for antiviral activity. Results were calibrated against the National Institutes of Health reference standard number Gg02-901-533.

Depletion of Thy-1+ cells. The Cosentino and Cathcart modification (4) of the panning method of Wysocki and Sato (24) was used to deplete $T$ cells from the total spleen cell population. Goat anti-rabbit immunoglobulin $\mathrm{G}$ (heavy and light chains) (Zymed, San Francisco, Calif.) was diluted to $10 \mu \mathrm{g} / \mathrm{ml}$ in $0.05 \mathrm{M}$ Tris ( $\mathrm{pH}$ 9.5) and was added to square $(100$ by $100 \mathrm{~mm})$ bacterial grade polystyrene petri dishes $(10$ $\mathrm{ml}$ per plate). The plates were incubated for $1 \mathrm{~h}$ at RT and washed three times with 5-ml amounts of cold complete medium. Prepared plates were filled with $10 \mathrm{ml}$ of complete medium and stored at $4^{\circ} \mathrm{C}$ until use. Cells to be depleted were prepared at $3.5 \times 10^{7}$ cells in $1 \mathrm{ml}$ of complete medium, and $25 \mu \mathrm{l}(1: 40)$ of rabbit anti-mouse $\mathrm{T}$ cell serum (anti-Thy1) (Cedarlane, Hornby, Ontario, Canada) was added. Following a 30-min incubation, the cells were washed three times with RPMI 1640 and suspended in $3 \mathrm{ml}$ of complete medium and drops of the suspensions were placed on the centers of the prepared plates; cells not exposed to anti-Thy1 were also added in drops to the centers of prepared plates. The plates were then incubated at RT for $45 \mathrm{~min}$. Following incubation, the plates were washed three times with 5-ml amounts of complete medium and the washings were collected. The depleted cells contained $<2 \%$ Thy $-1+$ cells, as determined by immunofluorescence.

In situ hybridization. The modified panning method $(4,24)$ was used to isolate populations of spleen cells expressing AGM1, L3T4, or Lyt-2 membrane antigens. Rabbit AAGM1 serum was obtained from Wako Chemicals USA, Dallas, Tex., and used to isolate AGM1+ cells from the mouse spleen cell preparations. AAGM1 treatment of 9-week-old ICR Swiss mice eliminated NK cell function as measured by cytotoxicity (2). Anti-L3T4 (rat monoclonal antibody reactive with $\mathrm{T}$ cell surface antigen $\mathrm{L} 3 \mathrm{~T} 4$ which was produced by GK1.5 hybridoma; ATCC no. TIB 207) and anti-Lyt-2 (rat monoclonal antibody reactive with Lyt- 2 cell surface antigen which was produced by 53-6.72 hybridoma; ATCC no. TIB 105) were gifts from Randall A. Smith (Wright State University, Dayton, Ohio) and were used as concentrated hybridoma supernatant fluids. Microscope slides ( 75 by $25 \mathrm{~mm}$ ) were cut from square bacterial grade polystyrene petri dishes. To an 8-mm circle etched onto the surface of each slide was added $75 \mu$ l of a 1:10 dilution of antibody in $0.05 \mathrm{M}$ Tris ( $\mathrm{pH}$ 9.5). Following a 1-h RT incubation, the slides were washed for several minutes in cold complete RPMI 1640. Cells to be probed were diluted to $1 \times 10^{7} / \mathrm{ml}$ to $2 \times 10^{7} / \mathrm{ml}$, and $75 \mu \mathrm{l}$ was added to the antibody-coated circle on each slide. After a 30-min RT incubation, the slides were washed by dipping them in complete RPMI 1640 until all nonadherent cells were removed, as determined microscopically. The cells were then fixed in $4 \%$ paraformaldehyde- $5 \mathrm{mM} \mathrm{MgCl}$ (pH 7.0) for $15 \mathrm{~min}$, and the cells were stored in $70 \%$ ethanol at $4^{\circ} \mathrm{C}$ until used. In each case, the purity of the cell preparations obtained by panning was in excess of $95 \%$, with individual samples ranging in purity from $>95$ to $>98 \%$. The cells were rehydrated in phosphate buffered saline plus 5 $\mathrm{mM} \mathrm{MgCl}_{2}$ (pH 7.0) and then in $0.2 \mathrm{M}$ Tris- $-0.1 \mathrm{M}$ glycine ( $\mathrm{pH} 7.4), 15 \mathrm{~min}$ each. Immediately prior to hybridization, the cells were incubated for $5 \mathrm{~min}$ at $70^{\circ} \mathrm{C}$ in $50 \%$ formamide$4 \times \operatorname{SSC}(3 \mathrm{M} \mathrm{NaCl}, 0.3 \mathrm{M}$ trisodium citrate [pH 7.0]). The in situ hybridization procedure of Lawrence and Singer (14) as modified by Kasaian and Biron was used (12). Murine IFN- $\gamma$ cDNA, originally obtained from Ken-ichi Arai (DNAX Research Institute, Palo Alto, Calif.), was a gift from Howard A. Young (National Cancer Institute, Frederick, Md.) with permission from Arai. $\beta$-Actin cDNA was obtained from I. Michael Leffak (Wright State University, Dayton, Ohio) and was used with the permission of Don W. Cleveland (Johns Hopkins University, Baltimore, Md.). A kit (Boehringer GmbH, Mannheim, Federal Republic of Germany) utilizing the random hexanucleotide priming method of Feinberg and Vogelstein (5) was used to label the cDNA with $\left[{ }^{35}\right.$ S]dATP (Amersham Corp., Arlington Heights, Ill.). The probes were labeled to a specific activity of $1 \times 10^{8}$ to $5 \times 10^{8} \mathrm{cpm} / \mu \mathrm{g}$ and denatured by boiling in $5 \mu$ l of formamide (Bethesda $\mathrm{Re}$ search Laboratories, Inc., Gaithersburg, Md.). Five microliters each of denatured probe and hybridization mixture (20\% dextran sulfate, $0.2 \%$ nuclease-free bovine serum albumin [Boehringer], $4 \times$ SSC, vanadyl complex 1:20 [Bethesda Research Laboratories], $10 \mathrm{mM}$ dithiothreitol [Sigma Chemical Co., St. Louis, Mo.]) were mixed and centrifuged briefly to remove bubbles. This mixture was transferred to a cover slip ( 18 by $18 \mathrm{~mm}$ ), which was then placed over the cells. The slides were gently covered with Parafilm and placed in a humidified chamber at $37^{\circ} \mathrm{C}$ for $3 \mathrm{~h}$. Following hybridization, the slides were given two 15 minute washes at $43^{\circ} \mathrm{C}$ in each of the following: $60 \%$ formamide $-2 \times \mathrm{SSC}, 60 \%$ formamide $-1 \times$ SSC, and $1 \times$ SSC. The slides were then air dried, dipped in Kodak type NTB-2 nuclear track emulsion, exposed for 7 days at $4^{\circ} \mathrm{C}$, developed, stained for $30 \mathrm{~min}$ with a 1:20 dilution of Accustain (modified Giemsa stain; Sigma Diagnostics, St. Louis, Mo.), rinsed in distilled water, and air dried.

Statistics. The level of significance of differences between test groups was determined by Student's $t$ test. The error bars in Fig. 1 represent the standard errors of the means for values obtained from five individual mice.

\section{RESULTS AND DISCUSSION}

Following infection with EMCV-D, spleen cell cultures from female ICR Swiss mice produced a larger early (8 to 16 $h$ p.i.) IFN- $\gamma$ response than did infected cells from males (16). An AGM1 + cell was responsible for this production of IFN- $\gamma$ (16). Staphylococcal enterotoxin A (SEA), a potent inducer of IFN- $\gamma$ in murine spleen cell cultures (21), also stimulated an earlier ( $12 \mathrm{~h}$ p.i.) and significantly greater $(P<$ 0.02 ) production of IFN- $\gamma$ by AGM $1+$ cells in spleen cell cultures from female ICR Swiss mice in comparison with the response seen in SEA-stimulated cultures of spleen cells from males of this strain (M. G. Tokman, H. I. McFarland, E. J. Ball and N. J. Bigley, manuscript submitted). But the T cells (Thy-1+ cell fraction containing L3T4+ and Lyt-2+ cells) from both sexes showed no difference in the amount of IFN- $\gamma$ produced at $20 \mathrm{~h}$ after exposure to SEA. This latter observation indicated that there is no defect in the T-cell mechanism for IFN- $\gamma$ production in the male ICR Swiss mouse. When the mouse spleen cells were cultured in the presence of Formalin-treated Salmonella typhimurium SR- 


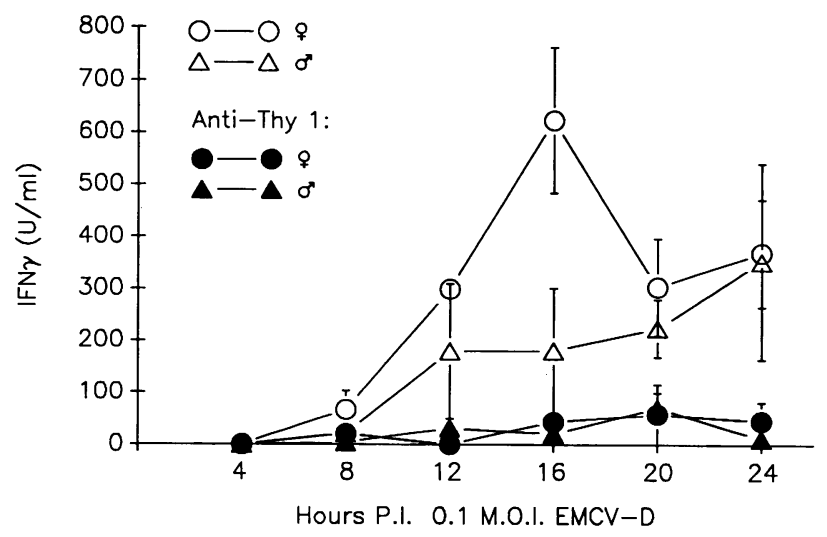

FIG. 1. IFN- $\gamma$ production by T-cell-depleted cell cultures after infection with EMCV-D. T cells were removed by panning with polyclonal rabbit anti-Thy-1. Control cells were panned without anti-Thy- 1 treatment. IFN- $\gamma$ activity was assayed by plaque reduction of vesicular stomatitis virus on mouse L929 cells and typed by neutralization with a hamster monoclonal anti-mouse IFN- $\gamma$ antibody. Each point represents the mean value for five individual mice. M.O.I., Multiplicity of infection. Error bars indicate standard errors.

11 or RIA in concentrations varying from 10 to $10^{7}$ bacteria per $10^{5}$ spleen cells, no IFN activity was observed in samples collected periodically throughout a 72-h culture period (R. E. Curiel and N. J. Bigley, unpublished observations). This set of control experiments suggests that IFN production by spleen cells from ICR Swiss mice following exposure to either EMCV-D or SEA was not due to contamination by endotoxin.
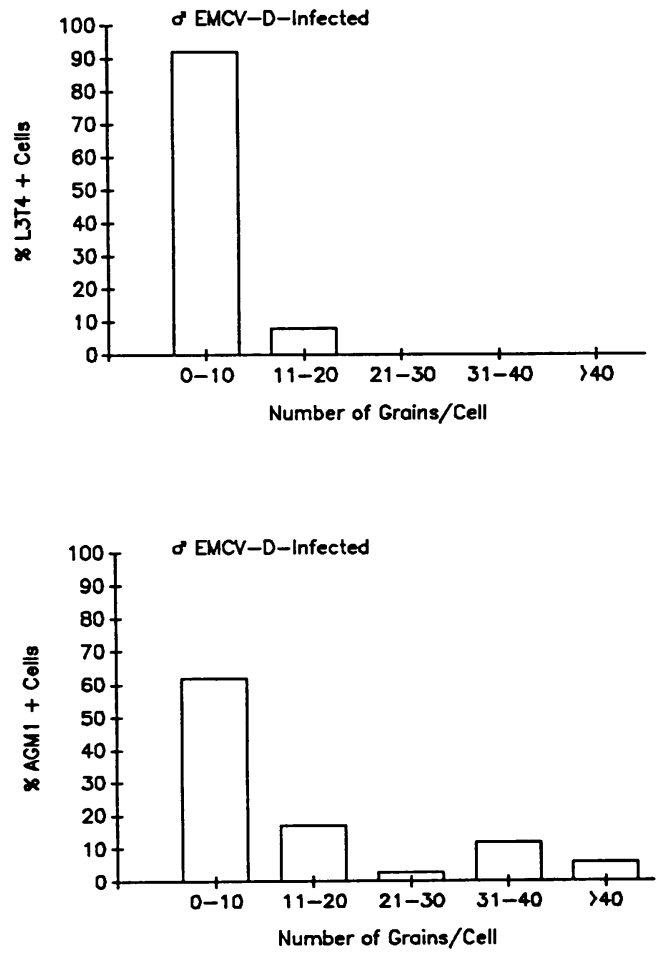

FIG. 2. In vitro production of IFN- $\gamma$ gene transcripts by AGM1+ spleen cells $9 \mathrm{~h}$ p.i. with EMCV-D. AGM1+ cells were enriched by panning them onto polystyrene microscope slides; the enriched cell population was $>98 \%$ positive for the AGM1 marker. In situ hybridizations with a murine IFN- $\boldsymbol{\gamma}$ cDNA probe were performed to identify cells containing IFN- $\boldsymbol{\gamma}$ mRNA.

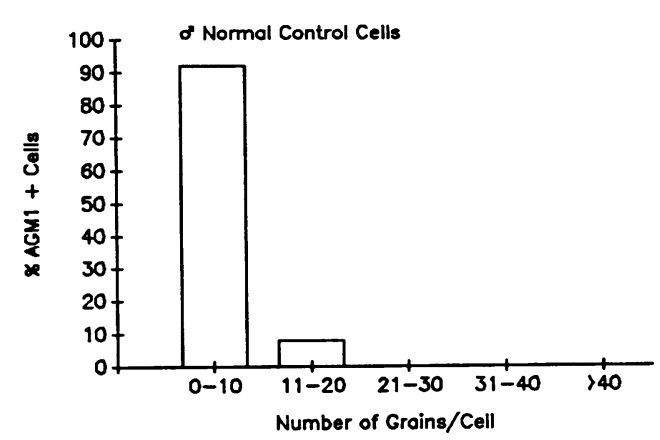

In this study, the phenotype of the cells involved in the early production of IFN- $\gamma$ by EMCV-D-infected spleen cell cultures was further characterized. Thy-1+ cells were depleted from spleen cell suspensions by panning with rabbit anti-mouse $\mathrm{T}$-cell serum prior to culture with virus at a multiplicity of infection of 0.1 (Fig. 1). The sex difference in IFN- $\gamma$ production occurred as late as $16 \mathrm{~h}$ p.i. in the experiments shown in Fig. 1 and not at $12 \mathrm{~h}$ p.i., which is observed in most experiments. In these particular experiments, the control cells were panned on anti-rabbit immunoglobulin G-coated slides which undoubtedly removed many cells bearing $\mathrm{Fc}$ receptors for immunoglobulin $\mathbf{G}$ (e.g., B cells, NK cells, and macrophages). Consequently, the ratios of the various cell types and dynamics of cell interaction were probably altered, leading to later production of IFN- $\gamma$ by virus-infected splenocytes from both sexes of ICR Swiss mice; this possibility was not explored. Supernatant fluid samples were harvested from the cultures at 4-h intervals for $24 \mathrm{~h}$. Removal of Thy-1+ cells nearly eliminated the capacity of female spleen cells for IFN- $\gamma$ production over the 24-h period following infection. Individual cultures from each of the spleen cell preparations from 5 female mice in which the Thy-1+ cells had been depleted showed significant $(P<0.05)$ reductions in IFN- $\gamma$ production after infection with EMCV-D over that seen in uninfected cell cultures at 12,16 , and $24 \mathrm{~h}$ p.i. Although a reduction in production of IFN- $\gamma$ by virus-infected compared with uninfected cells in Thy-1+ cell-depleted spleen cultures from males was seen at $20 \mathrm{~h}$ p.i., no significant differences in IFN- $\gamma$ production occurred in the infected or uninfected cultures from male mice. The Thy- 1 antigen is a cell surface marker found on all murine $\mathrm{T}$ cells and about $50 \%$ of NK cells (10). These observations suggest that Thy-1+ cells are important for

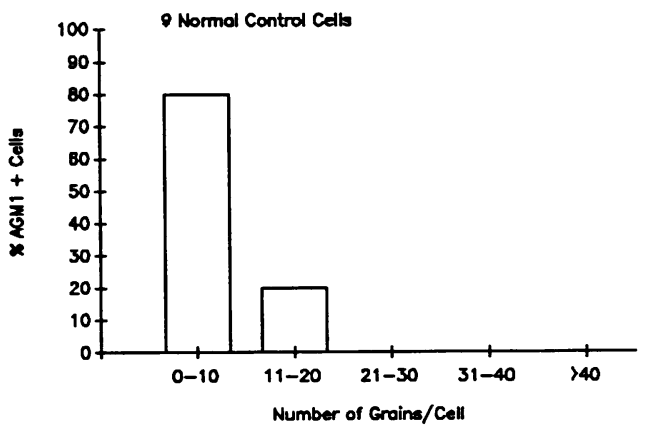



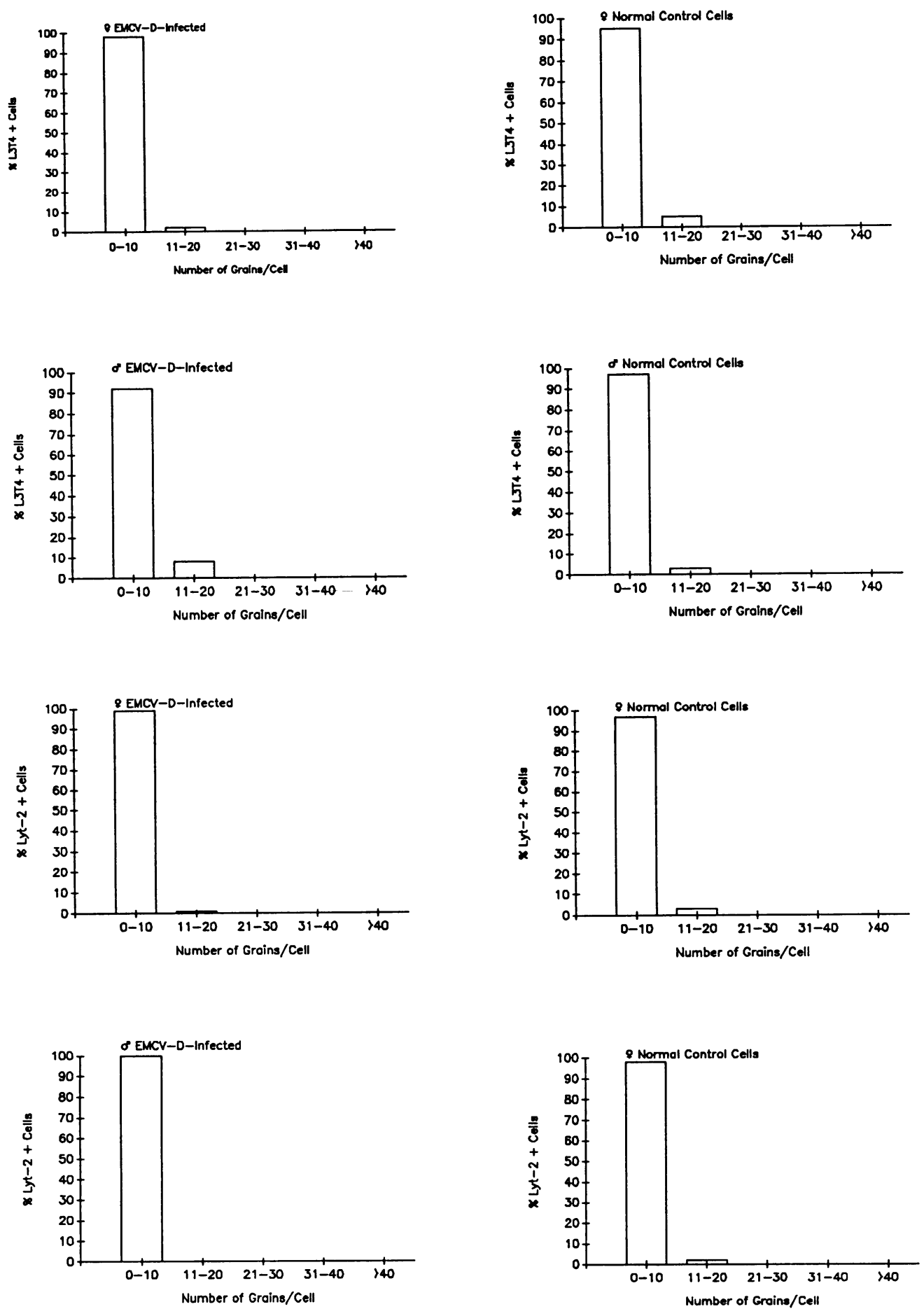

FIG. 3. In vitro production of IFN- $\gamma$ mRNA by L3T4+ and Lyt-2+ spleen cells $9 \mathrm{~h}$ p.i. with EMCV-D. Populations of L3T4+ and Lyt-2+ spleen cells were isolated by panning, as described in Materials and Methods; cells enriched by this method were $>98 \%$ positive for the selected marker. Cells containing IFN- $\gamma$ gene transcripts were identified by in situ hybridization with a murine IFN- $\gamma$ cDNA probe.

IFN- $\gamma$ production by virus-infected spleen cells throughout the 24-h observation period. From these results (Fig. 1), it was not possible to determine whether the early IFN- $\gamma$ producing cell was a Thy-1+ NK cell, a Thy-1- NK cell, or the result of a $\mathrm{T}$ cell-NK cell interaction.

Previously, we found that an AGM1 spleen cell was responsible for at least a portion of the late, IL-2-dependent
IFN- $\gamma$ production in EMCV-D-infected spleen cell cultures of both sexes of ICR Swiss mice (16). The observation that neutralization of IL-2 activity in the virus-infected spleen cell cultures with a monoclonal antibody specific for mouse IL-2 removed only the later-appearing $(>16 \mathrm{~h})$ peak of IFN- $\gamma$ production (16), in combination with the results obtained when Thy-1+ cells were depleted (Fig. 1), suggests that the 

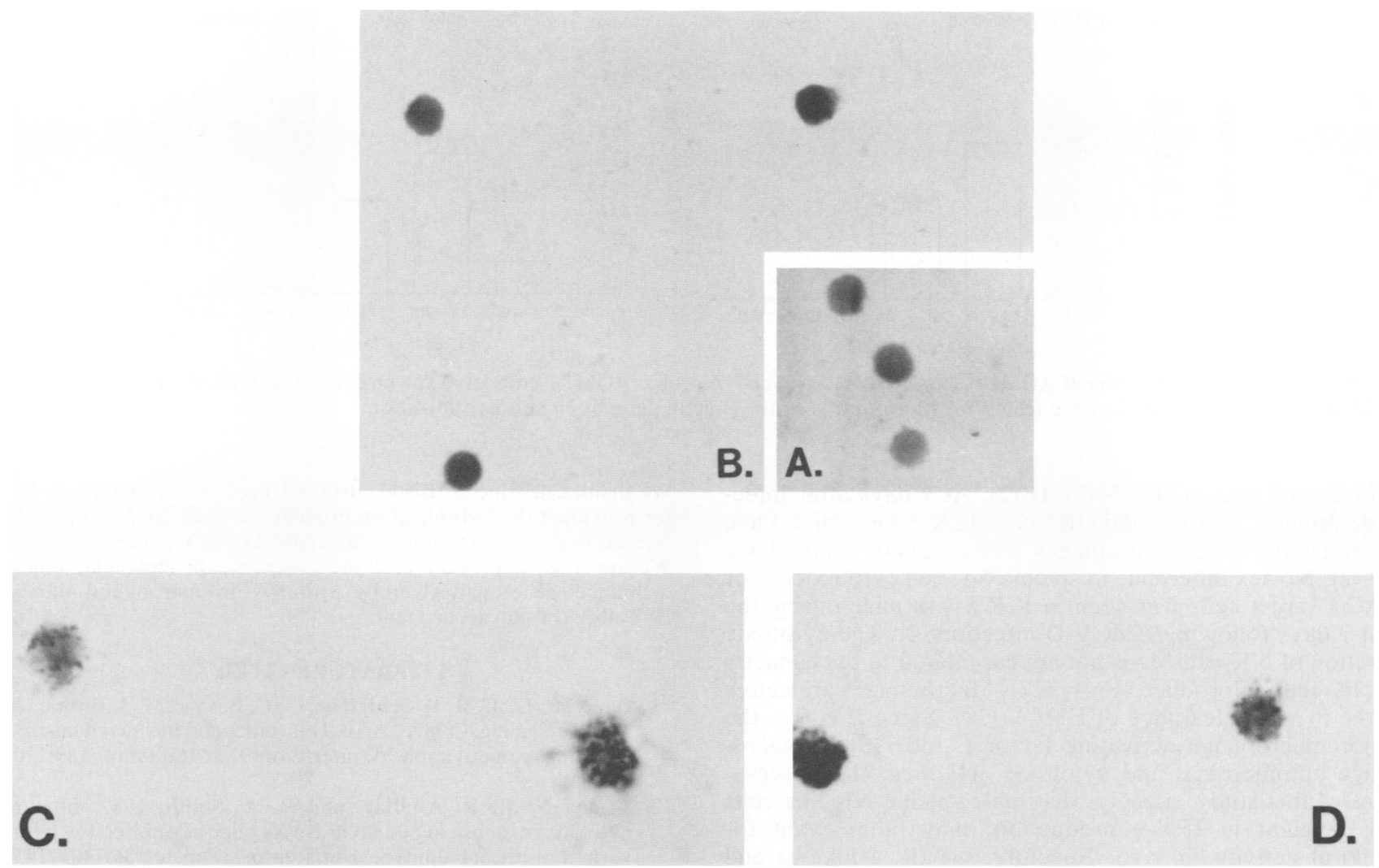

FIG. 4. In situ hybridization of spleen cells from ICR Swiss mice at $9 \mathrm{~h}$ p.i. with an IFN- $\gamma$ cDNA probe $(1,000 \times$ magnification). (A) Lyt-2+ cells; (B) L3T4 + cells; (C) AGM1 + cells from female mice cultures; (D) AGM1 + cells from male mouse cultures.

cell responsible for the late, IL-2-dependent production of IFN- $\gamma$ in virus-infected spleen cell cultures of both sexes is an AGM1 Thy-1 + T cell. The T-cell subtype involved in the production of the IL-2-dependent IFN- $\gamma$ was not determined.

Is the AGM1 + cell which is the early IFN- $\gamma$ producer an NK cell? To answer this question, an in situ hybridization procedure was used to probe AGM1+ cells with cDNA specific for IFN- $\gamma$ gene transcripts. Since IFN- $\gamma$ mRNA levels closely parallel the amount of IFN- $\gamma$ protein produced by two T-cell lines (11) and studies on IFN- $\gamma$ gene regulation have identified regulation only at the transcriptional level $(8$, $9,22,23,26)$, the presence of IFN- $\gamma$ in a particular cell type is strong evidence that cell type is producing IFN- $\gamma$ protein. Cells were harvested from EMCV-D-infected spleen cell cultures at 4 and $9 \mathrm{~h}$ p.i. No IFN- $\gamma$ mRNA was observed in infected cells harvested at $4 \mathrm{~h}$ p.i. (data not shown). Since Thy- $1+$ cells were involved in production of IFN- $\gamma$ early $(<16 \mathrm{~h})$ and later $(>16 \mathrm{~h})$ after virus infection of the spleen cell cultures and because we had no way to determine if the AGM1 + NK-like cells producing IFN- $\gamma$ early after infection also bore the Thy-1 membrane marker, monoclonal antibodies to T-cell-specific membrane markers L3T4 and Lyt-2 were used to isolate $\mathrm{T}$ cells after infection. AGM1+, Lyt$2+$, and L3T4+ cells were tested for the presence of IFN- $\gamma$ transcripts at $9 \mathrm{~h}$ after infection of spleen cells from ICR Swiss mice with EMCV-D at a multiplicity of infection of 0.1 (Fig. 2 and 3).

No IFN- $\gamma$ mRNA was present in cells bearing the T-cell markers L3T4 and Lyt-2 (Fig. 3). In samples of infected spleen cells from both sexes of ICR Swiss mice, only
AGM1 + cells collected at 9 h p.i. contained IFN- $\gamma$ mRNA (Fig. 2 and 4). A positive cell (i.e., a cell that contained IFN- $\gamma$ gene transcripts) was defined as a cell with greater than 3 standard deviations above the mean number of grains of emulsion in a similarly treated cell of the same type from an uninfected spleen cell culture. Of the virus-infected AGM1 + cells examined, $58 \%$ were positive for IFN- $\gamma$ gene transcripts in the female preparations and $21 \%$ were positive in the male preparations. This sex difference in the percentage of AGM1+ spleen cells exhibiting IFN- $\gamma$ mRNA at $9 \mathrm{~h}$ after virus infection reflects the relative levels in early production of IFN- $\gamma$ (e.g., at $12 \mathrm{~h}$ p.i.) seen previously (16). The early AGM1+ IFN- $\gamma$-producing cell in these virusinfected spleen cell cultures is likely an NK cell. Since the AGM1 marker is displayed by some mature murine $T$ cells $(13,20)$, these cells will be referred to as NK-like cells. No difference was seen in $\beta$-actin gene transcripts in infected and uninfected AGM1+ spleen cell preparations from female mice at $9 \mathrm{~h}$ p.i. (Fig. 5).

A $\mathrm{T}$-cell-independent mechanism for IFN- $\gamma$ production and subsequent activation of macrophages, including an IFN- $\gamma$-induced increase in expression of membrane Ia antigens, was described by Bancroft and co-workers in Listeriainfected mice with the severe combined immunodeficiency mutation (1). Because these mice lack detectable T-cell functions, NK cells were suggested as the probable producers of IFN- $\gamma(1)$. In contrast to those from disease-resistant female ICR Swiss mice, macrophages from disease-susceptible male ICR Swiss mice are impaired in their ability to generate hydrogen peroxide and in their capacity to show an increase in expression of Ia antigens in the first $24 \mathrm{~h}$ after 

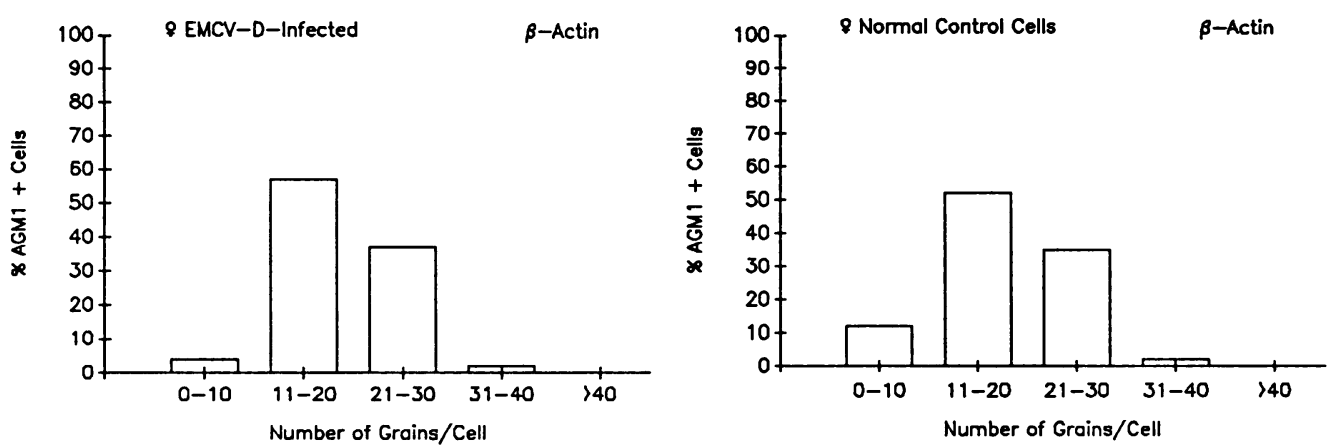

FIG. 5. In situ hybridization of AGM1+ cells with a $\beta$-actin cDNA probe. AGM1+ cells from spleen cell cultures identical to those probed for IFN- $\gamma$ transcripts (Fig. 2) were tested for transcription of the $\beta$-actin gene by in situ hybridization.

infection of mice with EMCV-D (2). At 7 days after infection, females and nondiabetic male ICR Swiss mice have cleared virus from their spleens while diabetic males have not (2). No sex difference in splenic NK cell cytotoxicity for YAC-1 target cells was seen in ICR Swiss mice during the first 7 days following EMCV-D infection (2). The cytotoxic function of NK cells does not appear related to the capacity of NK cells to produce IFN- $\gamma$ (17). Macrophages are active in the in vitro clearance of EMCV (19). Since IFN- $\gamma$ is the major macrophage activating factor $(3,15,18)$ of macrophage antimicrobial and cytotoxic activities, the observations of this study, namely, that male splenic NK-like cells are deficient in IFN- $\gamma$ production, may be relevant for antiviral activity in vivo. Recently, we (R. Ishikawa and N. J. Bigley, Viral Immunology, in press) have found that the adherent cell population is necessary for IFN- $\gamma$ production by the AGM1+ cells in this virus-spleen cell culture system, that no tumor necrosis factor $\alpha$ was detected in the spleen cell cultures following infection with EMCV-D, that addition of a rabbit polyclonal anti-murine IFN- $\alpha / \beta$ also inhibits formation of IFN- $\gamma$ in this system, and that virusinfected female spleen cells produce an earlier $(4 \mathrm{~h}$ p.i.) and greater IFN- $\alpha / \beta$ response than do comparable cultures of infected male spleen cells. Also, addition of exogenous mouse IFN $-\alpha / \beta$ restored the ability of the adherent celldepleted spleen cell cultures to produce IFN- $\gamma$ at $12 \mathrm{~h}$ after infection with EMCV-D. The capacity for IFN- $\gamma$ production was greatly enhanced by virus-infected spleen cells taken from males that had received pharmacologic doses of estrone over a 7-day period; comparable doses of testosterone given to ICR Swiss females over the same period did not diminish the capacity of their spleen cells to produce IFN- $\gamma$ after infection with EMCV-D. Molecular evidence further defining this phenomenon has recently been provided by Fox et al. (H. Fox, B. Bond, and T. G. Parslow, personal communication; manuscript submitted), who found that several estrogen-responsive elements lie upstream from the promoter for IFN- $\gamma$ production; these elements up-regulate expression directed by the promoter. Collectively, these results suggest that an adherent, IFN- $\alpha / \beta$-producing cell (most likely, a macrophage) first produces IFN- $\alpha / \beta$ in response to EMCV-D infection; the IFN- $\alpha / \beta$ induces the NK-like cells to produce IFN- $\gamma$; and then the IFN- $\gamma$ further primes the macrophages for activation.

\section{ACKNOWLEDGMENTS}

We thank Howard A. Young, National Cancer Institute, Frederick, Md., for providing the cDNA probe for mouse IFN- $\gamma$, for his interest in this work, and for his critical review of the manuscript.
We thank Christine A. Biron, Brown University, Providence, R.I., for providing the hybridization procedure which was used, for her interest in the project, and for her critical review of the manuscript. We are most appreciative of the assistance in molecular biology techniques generously given by Arthur A. Branstrom and Marshall E. Tolbert of our department.

\section{LITERATURE CITED}

1. Bancroft, G. J., R. D. Schreiber, G. C. Bosma, M. J. Bosma, and E. R. Unanue. 1987. A T cell independent mechanism of macrophage activation by interferon- $\gamma$. J. Immunol. 139:11041107.

2. Bigley, N. J., R. A. Blay, and R. A. Smith. 1987. Impaired cytokine response in male ICR Swiss mice after infection with D variant of encephalomyocarditis virus. Diabetes 36:1408-1413.

3. Cohn, Z. A. 1978. The activation of mononuclear phagocytes: fact, fancy, and future. J. Immunol. 121:813-816.

4. Cosentino, L. M., and M. K. Cathcart. 1987. A multistep isolation scheme for obtaining CD16+ human natural killer cells. J. Immunol. Methods 103:195-204.

5. Feinberg, A. P., and B. Vogelstein. 1983. A technique for radiolabeling DNA restriction endonuclease fragments to high specific activity. Anal. Biochem. 132:6-13.

6. Giron, D. J., and R. R. Patterson. 1982. Effect of steroid hormones on virus-induced diabetes mellitus. Infect. Immun. 37:820-822.

7. Giron, D. J., and F. F. Pindak. 1969. Propagation of MM virus in L cells. Appl. Microbiol. 17:811-814.

8. Hardy, K. J., B. M. Peterlin, R. E. Atchison, and J. D. Stobo. 1985. Regulation of expression of the human interferon- $\gamma$ gene. Proc. Natl. Acad. Sci. USA 82:8173-8177.

9. Heckford, S. E., E. P. Gelman, C. L. Agnor, S. Jacobson, S. Zinn, and L. A. Matis. 1986. Distinct signals are required for proliferation and lymphokine gene expression in murine $\mathrm{T}$ cell clones. J. Immunol. 137:3652-3663.

10. Herberman, R. B., M. E. Nunn, and H. T. Holden. 1978. Low density of thy 1 antigen on mouse effector cells mediating natural cytotoxicity against tumor cells. J. Immunol. 121:304 309.

11. Herold, K. C., D. W. Lancki, D. E. Dunn, K.-I. Arai, and F. W. Fitch. 1986. Activation of lymphokine genes during stimulation of cloned T cells. Eur. J. Immunol. 16:1533-1538.

12. Kasaian, M. T., and C. A. Biron. 1989. The activation of IL-2 transcription in L3T4+ and Lyt-2+ lymphocytes during virus infection in vivo. J. Immunol. 142:1287-1292.

13. Knobloch, C., and G. Dennert. 1988. Asialo-GM1-positive T killer cells are generated in $F_{1}$ mice injected with parental spleen cells. J. Immunol. 140:744-749.

14. Lawrence, J. B., and R. H. Singer. 1985. Quantitative analysis of in situ hybridization methods for the detection of actin gene expression. Nucleic Acids Res. 13:1777-1799.

15. Le, J., W. Prensky, Y. K. Yip, Z. Chang, T. Hoffman, H. C. Stevenson, I. Balazs, J. R. Sadlick, and J. Vilcek. 1983. Activation of human monocyte cytotoxicity by natural and recombi- 
nant immune interferon. J. Immunol. 131:2821-2826.

16. McFarland, H. I., and N. J. Bigley. 1989. Sex-dependent, early cytokine production by NK-like spleen cells following infection with the D variant of encephalomyocarditis virus (EMCV-D). Viral Immunol. 2:205-214.

17. Nagler, A., L. L. Lanier, S. Cwirla, and J. H. Phillips. 1989. Comparative studies of human FcRIII-positive and negative natural killer cells. J. Immunol. 143:3183-3191.

18. Roberts, W. K., and A. Vasil. 1982. Evidence for the identity of murine $\gamma$ interferon and macrophage activating factor. J. Interferon Res. 2:519-532.

19. Soldateschi, D., D. Boraschi, and A. Tagliabue. 1985. Natural antiviral activity of mouse macrophages against encephalomyocarditis virus. Antiviral. Res. 5:217-227.

20. Suttles, J., G. A. Schwarting, and R. D. Stout. 1986. Flow cytometric analysis reveals the presence of asialo GM1 on the surface membrane of alloimmune cytotoxic T lymphocytes. J. Immunol. 136:1586-1591.

21. Torres, B. A., J. K. Yamamoto, and H. M. Johnson. 1982. Cellular regulation of gamma interferon production: Lyt pheno- type of the suppressor cell. Infect. Immun. 35:770-776.

22. Weiss, A., R. L. Wiskocil, and J. D. Stobo. 1984. The role of T3 surface molecules in the activation of human T cells: a twostimulus requirement for IL-2 production reflects events occurring at a pre-translational level. J. Immunol. 133:123-128.

23. Wiskocil, R. A., J. Weiss, J. Imboden, R. Kamin-Lewis, and J. Stobo. 1985. Activation of a human T cell line: a two-stimulus requirement in the pretranslational events involved in the coordinate expression of interleukin 2 and $\gamma$-interforon genes. $J$. Immunol. 134:1599-1603.

24. Wysocki, L. J., and V. L. Sato. 1978. "Panning" for lymphocytes: a method for cell selection. Proc. Natl. Acad. Sci. USA 75:2844-2848.

25. Yoon, J.-W., P. R. McClintock, T. Onodera, and A. L. Notkins. 1980. Virus-induced diabetes mellitus. XVIII. Inhibition by a nondiabetogenic variant of encephalomyocarditis virus. J. Exp. Med. 152:878-892.

26. Young, H. A., and J. R. Ortaldo. 1987. One-signal requirement for interferon-gamma production by large granular lymphocytes. J. Immunol. 139:724-727. 